\title{
APLIKASI KONSEP KHULTAH DALAM PENGIRAAN ZAKAT DI MALAYSIA: ANALISIS ISU, CABARAN DAN PENYELESAIANNYA
}

\section{Application of Khultah Concept in Zakāh Calculation in Malaysia: Analysis of Issues, Challenges and Its Solutions}

\author{
Ahmad Zakirullah Mohamed Shaarani ${ }^{1}$ \\ Ridzwan Ahmad ${ }^{2}$
}

\begin{abstract}
The concept of khultah in the discussion of zakāh connotes a mixure of zakatable assets owned by several owners and calculated as a single entity. In the contemporary period, many zakatable assets are being kept in a common fund that fits the definition of khultah of zakāh, and is thus subject to the zakāh obligation. This includes cash deposited in accounts, such as the Tabung Haji fund; accounts in banks, such as savings, checking, and investments accounts; Employees Provident Fund (EPF); as well as corporations, etc.. However, looking at the current practices
\end{abstract}

\footnotetext{
Ph.D candidate, Department of Fiqh and Usul al-Fiqh, Academy of Islamic Studies, University of Malaya, 50603 Kuala Lumpur, zakirullah_77@icloud.com

2 Senior Lecturer, Department of Fiqh and Usul al-Fiqh, Academy of Islamic Studies, University of Malaya, 50603 Kuala Lumpur, ridzwan@um.edu.my
} 
of zakāh calculation, it is evident that the khultah concept has been neglected. In fact, its practice and implementation among the zakāh collection bodies have not been standardized. Using the literature review methodology, this article aims to examine the views of Islamic jurists on the concept of khultah and its implementation and constraints that limit its implementation and any proposed resolutions, and how this concept can benefit the zakāh authorities. This research has found that although the concept of khultah in zakāh collection faces many challenges for implementation it can be optimized in expanding zakāh collection, thus empowering its role in fulfilling the needs of the Muslim society.

Keywords: zakāh, khultah, syuyū', Tabung Haji

\section{PENGENALAN}

Zakat merupakan salah satu rukun Islam yang wajib dilaksanakan apabila telah cukup niṣāb dan hawlnya. Ia berperananan besar dalam pembangunan ekonomi umat Islam dengan menjadi pemangkin ekonomi golongan fakir dan miskin, pemacu pembangunan kecemerlangan modal insan melalui bidang dakwah dan pendidikan, juga sebagai pembantu bagi mereka yang berhutang, terputus bekalan dalam perjalanan dan sebagainya.

Dalam membincangkan tentang zakat, para ulama telah membincangkan tajuk berkaitan zakat ke atas harta khultah iaitu harta-harta yang dimiliki oleh beberapa pemilik yang dihimpunkan sehingga mencukupkan kadar niṣa $b$ zakat. Khulțh bermaksud aset-aset yang dimiliki oleh beberapa orang pemilik yang disimpan di tempat yang sama, dan segala pengurusan berkaitan dengannya diuruskan oleh satu pihak yang telah dilantik oleh pemilik-pemilik harta tersebut. ${ }^{3}$

Melihat kepada perbincangan ulama tentang konsep khultah ini, walaupun mazhab al-Shāfi' $\overline{1}$ menerima konsep khulțah dalam bab zakat, ${ }^{4}$ namun berdasarkan kepada pengamalan semasa konsep ini terutamanya apa yang diamalkan oleh institusi yang dipertanggungjawabkan mengutip zakat, ianya tidak menggambarkan khultah diamalkan sepenuhnya sebagaimana yang

3 Shams al-Dīn Muḥammad bin Aḥmad al-Sharbinī, Mughñ̄ al-Muhtāj ila Ma 'rifati Ma 'ānī Alfāz al-Minḥāj, vol. 2, ed. Toha 'Abd al-Raūf Sa'd (Qāhirah: Maktabah Tawfiqiyyah, t.t.), 79.

4 Shams al-Dīn Muḥammad bin Aḥmad al-Sharbinī, Mughñ̄ al-Muḥtāj ila Ma 'rifati Ma 'ānī Alfāza al-Minḥāj, vol. 2, 79. 
difahami dan dibahaskan oleh para ulama dari mazhab al-Shāfi' 1 . Sebahagian praktis semasa dalam soal kutipan zakat menggunakan khulțh sebagai asas pengiraan zakat, sementara sebahagian praktis yang lain pula tidak menggunakannya ${ }^{5}$ dan ini sebenarnya bertentangan dengan pegangan mazhab al-Shāfi'‘̄ yang menerima konsep khulțh dalam pengiraan zakat.

Justeru, artikel ini akan menganalisis pandangan para fuqaha terutama fuqaha dari mazhab al-Shāfi'i tentang konsep khultah dan jenis-jenis harta zakat yang tertakluk kepada pengiraan zakat berdasarkan konsep khultah, aplikasi khultah dalam praktis dan amalan semasa bagi kutipan zakat, permasalahan semasa yang berkaitan dengannya dan penyelesaiannya.

\section{DEFINISI KHULT TAH}

Dari segi bahasa, khultah bermaksud percampuran antara sesuatu dengan yang lain. Khalìt ialah yang berjiran, khiltah bermaksud pergaulan dan percampuran, dan khultah bermaksud al-Shirkah iaitu perkongsian, dan jamak kepadanya adalah khulata ${ }^{6}$ Firman Allah SWT yang berbunyi:

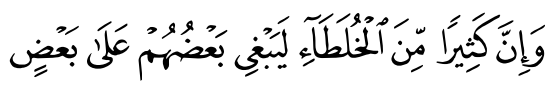

“...dan sesungguhnya kebanyakan dari orang-orang yang bergaul dan berhubungan (dalam berbagai-bagai lapangan hidup), setengahnya berlaku zalim kepada setengahnya yang lain...."

(Surah al-Șād, 38: 24)

Juga firmanNya:

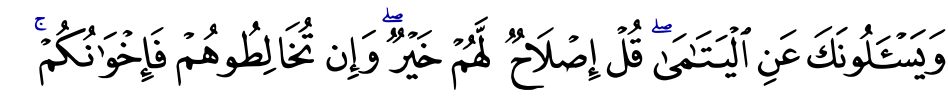

“....dan mereka bertanya lagi kepadamu (wahai Muhammad), mengenai (masalah) anak-anak yatim. Katakanlah: "Memperbaiki keadaan anak-anak yatim itu amatlah baiknya", dan jika kamu bercampur gaul dengan mereka (maka tidak ada

$5 \quad$ Ini akan dibincangkan di bawah tajuk "Aplikasi Semasa Khultah dan Kesannya dalam Pengiraan Zakat".

6 Ibn Faris, Aḥmad bin Faris, Mu 'jam Maqāyis al-Lughah, vol. 2, ed. 'Abd al-Salam Muḥammad Harun (Beirūt: Dār al-Fikr, 1979), 209; Ibn Manẓūr, Muḥammad bin Mukram, Lisān al- 'Arab, vol. 7 (Beirūt: Dār Șadr, t.t.), 291; Muḥammad bin Abū Bakr al-Rāzī, Mukhtār al-Sihhhah, vol. 1 (Lubnan: Maktabah Lubnan, 1986), 77. 

salahnya) kerana mereka itu ialah saudara-saudara kamu (yang
seagama).."

(Surah al-Baqārah, 2: 220)

Berdasarkan perbincangan di atas, khultah bermaksud percampuran dan dalam kebanyakan situasi, percampuran tersebut memberi kesan kepada hukum asal dan mengubahnya kepada hukum yang lain, seperti apa yang dapat dilihat dalam bab keharusan memegang mushaf jika ia bercampur dengan tafsir, ${ }^{7}$ hukuman qiṣa $s$ terhadap sekumpulan manusia yang membunuh, ${ }^{8}$ pelaburan yang bercampur antara aktiviti yang halal dan haram (mixed activities) dan sebagainya. Juga kesan khultah boleh dilihat dalam soal zakat ke atas binatang, barang perniagaan, emas/perak, dan sebagainya sebagaimana yang akan dibincangkan dalam penulisan ini nanti.

Dari segi istilah pula, khultah dalam bab zakat didefinisikan dengan maksud:

"Dua harta yang tertakluk kepada hukum zakat yang dimiliki oleh dua orang (atau lebih) yang dihimpun keduanya, dengan tujuan untuk perkongsian atau seumpamanya..." 9

Berdasarkan definisi khulțh ini, harta yang terhimpun yang dimiliki oleh beberapa orang akan dikenakan zakat secara kolektif sebagaimana halnya zakat

Sa'id al-Bakrī bin Muhammad Syața al-Dumyațī, Hāsyiyah I'ānah al-Ṭālibīn, vol. 1 (Beirūt: Dār al-Fikr, t.t.), 67; Ab̄̄ Zakariyya Yahyya bin Syaraf al-Nawāwī, Rawḍ̂h al-Ṭālibìn wa 'Umdah al-Muftìn, vol. 2 (Beirūt: Maktab al-Islāmī, 1991), 15.

8 Walaupun dari segi asal kaedah qiṣās itu satu nyawa akan dibalas satu, namun jika sekumpulan manusia melakukan satu pembunuhan, maka mereka akan dikenakan hukuman qișās berdasarkan konsep al-mașālih, sedang sebahagian ulama lagi mengatakan ia adalah berdasarkan konsep istihsān. Rujuk Shihāb al-Dīn Mahmūd bin Aḥmad al-Zanjānī, Takhrīj al-Furū' 'alā al-Ușūl (Qāhirah: Mu'assasah alRisālah, t.t.), 323.

9 Musțafā Khin, Musțafā Bugho, 'Alī Sharbajī, Fiqh al-Manḥajī 'alā Madhhab alImām al-Shāfi 'ì, vol. 1 (Damsyiq: Dār al-Qalam, cetakan ke 10, 2009), 308. Juga rujuk Muhammad bin Idrīs al-Shāfi' 1 , al-Umm, vol. 3, ed. Rifa'āt Fawzī 'Abd alMuțalib (Manșūrah: Dār al-Wafā', 2001), 33. Imam al-Ghazālī ada berkata:

"Pertama; dalam soal khultah dan syarat-syaratnya, dan hukum khultah adalah dua harta yang menempati tempat satu harta, kalau bercampurlah 40 ekor dengan 40 ekor milik orang lain, maka bagi kesemuanya (80 ekor) dikenakan seekor sahaja, dan kalau bercampur 20 ekor dengan 20 ekor milik orang lain maka bagi setiap orang dikenakan setengah ekor..." Lihat Abū Hamid Muhammad bin Muhammad al-Ghazālī, al-Wajīz fì al-Fiqh al-Shāfi 'ī, vol. 2, ed. 'Alī Mu'awwad, 'Adi 'Abd al-Mawjūd (Beirūt: Dār al-Arqām bin Abī al-Arqām, 1997), 217. 
dikenakan ke atas harta yang dimiliki oleh seseorang yang telah mencapai nișāb. ${ }^{10}$

\section{HADIS BERKAITAN KHULTAH DALAM ZAKAT}

Terdapat beberapa hadis ${ }^{11}$ Nabi SAW yang membicarakan tentang khultah dalam bab zakat, namun hadis sahih yang masyhur dalam bab khultah ini ialah

10 Abū Isḥāq Ibrahīm bin 'Alī al-Shirāzị, al-Muhazzab, vol. 1, ed. Muhammad Zuhaylī (Damsyīq: Dār al-Qalam, 1996), 493. Hannan 'Abd al-Rahmad Abū Mukh dalam bukunya mentarjihkan definisi yang mengatakan bahawa ia tidak disyaratkan, lihat Hannan 'Abd al-Rahmad Abū Mukh, Zakāt al-Syarikāh fì alFiqh al-Islāmī ('Ammān: Dār al-Ma'mūn, 2007), 102.

11 Selain dari hadis utama yang disebutkan dalam perbincangan berkaitan khultah ini, terdapat juga hadis-hadis lain seperti:

a) Dari Sa'd bin Abī Waqās pula beliau mendengar Rasulullah SAW bersabda;

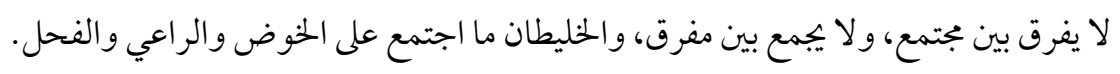

"Tidak dipisahkan di antara yang berhimpun dan tidak dihimpunkan di antara yang berpisah, dan percampuran di antara dua (khultah) itu adalah yang berhimpun tempat minum (kolam) pengembala dan kuda..." Dāruqutn̄i, "Alī bin 'Umar, Sunan Dāruqutnī, vol. 2, ed. Adil 'Abd al-Mawjūd, 'Alī Muhammad Mu'awwaḍ (Beirūt: Dār al-Ma'rifah, 2001), 271-272, "Bāb Tafsīr al-Khalīṭayn, Wa Mā Jā' fì Zakāt 'alā al-Khalịṭayn," hadis no. 1920; Abū Bakr Aḥmad bin Hussīn bin 'Alī al-Bayhaq̄i, Sunan al-Kubrā, vol. 4, ed. Muhammad 'Abd alQādir Ața (Beirūt: Dār al-Kutub al-'Ilmiyyah, cetakan ke-2, 2003), 176, "Kitāb al-Zakāt: Bāb Șadaqah al-Khulațā'," hadis no. 7333, 7334. Hadis ini sekalipun dikategorikan sebagai hadis $D a$ 'if namun maknanya adalah benar iaitu maksudnya diakui berdasarkan ijma ' dalam soal ini, bahkan maksud hadis bukanlah dari segi lafaz itu bahkan dari segi 'illah dari khultah itu iaitu untuk mengurangkan kos dan ianya juga wujud pada hadis yang disebutkan. Rujuk al-Ramlī, Muhammad bin Abī al-'Abbas, Nihāyah al-Muḥtāj ila Syarh Minhāj; beserta Hāsyiyyah 'Alī bin 'Alī al-Shabralamsī, Hāsyiyah Muhammad bin Aḥmad al-Maghzī al-Rasyid̄̄ (Beirūt: Dār al-Kutub al-'Ilmiyyah, 2003), 61; Shihāb al-Dīn Aḥmad bin 'Alī al'Asqalānī, al-Talkhīs al-Khabīr fì Takhrīj Ahāaìth al-Rāfi' '̄ al-Kabìr, vol. 2, ed. Hassan bin 'Abbas (t.t.p.: Mu'assasah Qurțubah, 1995), 306.

b) Hadis dari Su'ad bin Ghuflah di mana beliau berkata:

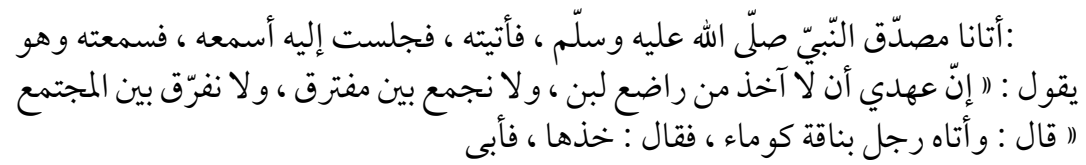


hadis riwayat Anas bin Mālik dari Abu Bakar RA bahawa Rasulullah SAW telah bersabda:

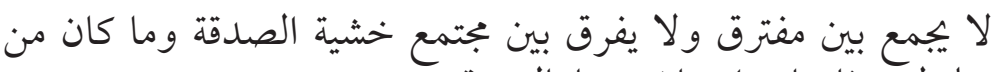

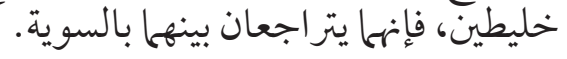

"Tidak dihimpunkan (harta zakat) yang terpisah dan tidak dipisahkan (harta zakat) yang terhimpun untuk mengelakkan dari zakat, dan dua orang yang bercampur (harta zakatnya) hendaklah dikeluarkan zakat daripada keduanya secara pro-rata..." 12

Imam Mālik menyebutkan bahawa maksud hadis ini ialah tiga orang yang mana setiap mereka memiliki 40 ekor kambing lalu wajiblah ke atas mereka zakat, namun mereka menghimpunkannya dengan tujuan untuk mengelakkan zakat dan (disebabkan himpunan tersebut) tidak wajib zakat ke atas mereka semua kecuali hanya seekor sahaja. Atau dua orang yang memiliki 202 ekor kambing, maka wajib ke atas mereka 3 ekor kambing, namun mereka memisahkan kambing-kambing tersebut sehingga tidak dikenakan ke atas mereka melainkan seekor sahaja (bagi setiap seorang). ${ }^{13}$

"Diceritakan kepadaku oleh mereka yang berjalan bersama pengutip zakat yang dilantik oleh Nabi SAW,- di zaman baginda SAW - bahawa mereka berkata: jangan diambil zakat terhadap binatang yang sedang menyusu, dan jangan menghimpunkan apa yang terpisah, dan jangan memisahkan apa yang telah berhimpun, kemudian beliau berkata: dan dia didatangi oleh seorang lelaki dengan unta yang besar, lalu tuannya berkata, ambillah unta ini, namun ia enggan mengambilnya.." Abū Bakr 'Abd Allāh bin Muhammad bin Abī Shaybah, Musnad Ibn Abī Shaybah, vol. 2, ed. 'Adīl bin Yūsuf al-Ghazadī, Aḥmad Farīd al-Mazīdī (Riyāẹ: Dār al-Wațan, t.t.), 41, no. hadis 549. Hadis ini dikategorikan sebagai hadis Hasan.

12 Shihāb al-Dīn Aḥmad bin 'Alī al-'Asqalānī, Fatḥ al-Bārī Syarah Ṣaḥ̄h Bukhārī, vol. 3, ed. 'Abd al-Qādir Shaybah al-Hạd (Riyāḍ: Maktabah al-Malik Faḥd alWațaniyyah, Amir Sulțān 'Abd al-'Azīz, 'Alī Saud), 368, "Kitāb al-Zakāt: Bāb Lā Yujma' Bayna Mutafarriq wa la Yufarraq Bayna Mujtami‘in,” hadis no. 1419, 1420. Juga rujuk Aḥmad bin al-Syuib al-Nasā'̄ , Sunan al-Nasā' $\bar{l}$, vol. 3, ed. 'Abd Allāh bin 'Abd al-Muhsīn (Qāhirah: Mu'assasah al-Risālah, 2001), 19, 20, "Kitāb al-Zakāt: Bab Zakāt al-Ibil,” hadis no. 2249, 2250; al-Bayhaq̄i, Aḥmad bin Husayn, ed. Muḥammad 'Abd al-Qādīr 'Ațā, Sunan al-Kubrāa, 167, hadis no. 7329, 7330, 7331, 7332 .

13 Abū al-Walīd Sulayman bin Khalaf al-Bājīi, al-Muntaqā Syarh al-Muwațta', vol. 2 (Mesir: Mațba'ah al-Sa'ādah, 1332), 136-137. 
Al-Shāfi'ī pula mengatakan hadis ini merujuk kepada tuntutan supaya pemberi modal dan pengusaha tidak mengasing atau mencampurkan harta zakat untuk mengelakkan dari dikenakan zakat yang lebih tinggi. ${ }^{14}$

\section{PENDAPAT ULAMA TENTANG KHULTAH DALAM ZAKAT}

Ulama telah berselisih pendapat tentang khultah dalam zakat kepada dua pendapat iaitu pendapat majoriti ulama dan pendapat mazhab Hanafī. ${ }^{15}$

\section{a) Majoriti Ulama (Ṭāwūs, 'Ața', Yahya bin Sa'id, mazhab al-Shāfi'ī, mazhab Mālikī dan mazhab Ḥanbalī)}

Khultah memberi kesan kepada pengiraan zakat dan ini adalah pendapat jumhur ulama, namun mereka berbeza pendapat dari segi jenis-jenis khultah, ${ }^{16}$

14 Shihāb al-Dīn Aḥmad bin 'Alī al-'Asqalānī, Fath al-Bārī Syarah Ṣaḥ̄h Bukhārī, vol. 3, 368-369. Juga rujuk al-Shawkānī, al-Raw ḍah al-Nadiyyah Syarh al-Durar al-Bahiyyah, vol. 1, 470 .

15 Ahmad bin Rusyd Ibn al-Rusyd, Bidāyah al-Mujtahid, dengan Hamish al-Sabīl al-Murshid ilā Bidāyah al-Mujtahid wa al-Nihāyah al-Muqtasid, vol. 2, ed. 'Abd Allāh Abadī (Qāhirah: Dār al-Salam, 1995), 622, 623; Abū al-Ḥassan 'Alī bin Muḥammad al-Māwardī, al-Hāwī al-Kabìr, vol. 4 (Beirūt: Dār al-Kutub al'Ilmiyyah, 1999), 94; 'Abd Allāh bin Aḥmad bin Qudāmah, al-Mughnī wa Yalīhi al-Syarh al-Kabìr, vol. 2 (Beirūt: Dār al-Kitāb al-'Arab̄i, t.t.), 530; Yūsuf alQaraḍāwī, Fiqh al-Zakāt, vol. 2 (Qāhirah: Mu'assasah al-Risālah, 2001), 255.

16 Bagi ulama yang menerima konsep khultah, mereka membahagikan khultah kepada dua jenis utama iaitu khulțah isytirāk dan khulțah awșāf. Khulțah isytirāk ialah harta yang dimiliki oleh dua atau tiga individu atau lebih secara pelbagai, sebagai contoh mereka membeli beberapa ekor binatang ternakan secara berkongsi dan setiap daripada mereka memiliki hak ke atas binatang-binatang tersebut tetapi tidak ditentukan yang mana satu milik mereka, atau ianya dikenali dengan pemilikan secara syuy $\bar{u}^{\prime}$ (undivided portion). Juga termasuk di sini khultah alsyuyu' iaitu perkongsian dalam pemilikan tanah, aset tetap, wang tunai, akaun bersama dan sebagainya selama mana pemilikan adalah berdasarkan nisbah sahaja, khulțah awșāf Iaitu diketahui siapakah pemiliknya tetapi dicampurkan untuk memudahkan penjagaan dari segi makanan, minuman dan sebagainya dan dari segi kemudahan, ia tidak ditentukan hak milik siapa. Asal khultah ini adalah untuk binatang sebagaimana dalam hadis, dan diqiyaskan bagi harta yang lain seperti tanaman dan sebagainya, timbul persoalan bagi mata wang, dan sebagainya selama mana pemilikan bukan berdasarkan nisbah tertentu, tetapi berdasarkan kepada jumlah tertentu maka ia dikira di bawah khulțah al-jiwār. Abū Zakariya Mạ̣y al-Dīn bin Sharaf al-Nawawī, al-Majmū'Syarh al-Muhazzab, vol. 5 
juga apakah jenis-jenis harta yang termasuk dalam skop khultah. Jumhur ulama berhujah dengan hadis daripada Saidina Anas RA yang diriwayatkan oleh al-Bukhārī yang telah disebutkan sebelum ini. ${ }^{17}$

Dalam soal ini al-Zanjān̄̄ ada berkata:

“..dan di antaranya (furū" dari kaedah zakat itu sebagai kewajipan harta); ialah, khultah memberi kesan kepada zakat, kerana ia menjadikan dua harta itu seperti satu, (dan dua pemilik itu seperti satu) dengan maksud jika seorang itu memiliki 20 ekor kambing, dan seorang yang lain pula memiliki 20 ekor lalu dicampurkan kambing keduanya, dan apabila cukup syaratsyaratnya (khultah) maka wajib ke atas keduanya zakat sesudah cukup hawl, iaitu keduanya perlu mengeluarkan seekor kambing dari jumlah 40 ekor (yang mereka miliki tersebut). Ini adalah berdasarkan kaedah yang telah kami telah sebutkan bahawa ianya (zakat) itu adalah kewajipan harta, ((dan rukun padanya adalah harta, tanpa melihat kepada pemilik, bahkan apa yang diambil kira adalah kewujudan harta))..." 18

Dalam soal jenis-jenis harta yang termasuk dalam skop pengiraan zakat berdasarkan konsep khultah, kebanyakan ulama yang menerima konsep khultah berpendapat bahawa ia hanya terpakai kepada binatang ternakan sahaja. Bagi selain dari binatang ternakan seperti tanaman, barang perniagaan, buah-buahan dan emas perak, kebanyakan mereka berpandangan bahawa khultah tidak terpakai kepada aset-aset jenis ini. Namun pendapat yang kuat (Azhār) dalam mazhab Shāfi'ì mengatakan bahawa khultah juga terpakai bagi aset-aset di atas dengan diqiyāskan kepada khulțh ke atas binatang, dan 'illahnya ialah adanya keringanan iaitu disebabkan adanya khultah maka ianya memberi keringanan dan kemudahan kepada pemilik harta dalam soal

(Jeddah: Maktabah Irshād, t.t.), 407; al-Ramlī, Nihāyah al-Muhtaj, vol. 3, 59-60; al-Sharbīn̄̄, Muḥammad bin Muḥammad, al-Iqnā'fì Hilli Alfāz Abì Syuja', vol. 1, ed. Muḥammad Mu'awwaḍ, 'Adil Aḥmad 'Abd al-Mawjūd (Beirūt: Dār al-Kutub al-'Ilmiyyah, 2004), 443. 'Abd al-Mālik bin 'Abd Allāh al-Juwaynī, Niḥ̂̄yah alMațlah fì Dirāyah al-Madhhab, vol. 3 (Jeddah: Dār al-Minhāj, cetakan pertama, 2007), 147-148. Shams al-Dīn Muhammad bin Aḥmad al-Sharbinī, Mughñ̄ alMuḥtāj ila Ma 'rifati Ma 'ān̄̄ Alfāz al-Minḥāj, vol. 2, 79-80.

17 Shihāb al-Dīn Aḥmad bin 'Alī al-'Asqalānī, Fatḥ al-Bārī Syaraḥ Ṣaḥ̄h Bukhārī, vol. 3, 368, "Kitāb al-Zakāt: Bāb Lā Yujma' Bayna Mutafarriq wa Lā Yufarraq Bayna Mujtami“in," hadis no. 1419, 1420.

18 Shihāb al-Dīn Mahmūd bin Aḥmad al-Zanjān̄̄, Takhrīj al-Furū' 'alā al-Ușūl, 115. 
pengurusan harta mereka, justeru disebabkan itu maka zakat dikenakan ke atas harta-harta mereka yang bercampur walaupun jika berdasarkan pengiraan zakat per individu, harta tersebut masih tidak mencapai kadar niṣab. ${ }^{19}$

Dariseginiat dalam soal khultah ini, walaupun sebahagianulamamengatakan perlunya niat dalam menjadikan suatu kumpulan wang yang dimiliki bersama itu harta-harta yang tertakluk kepada hukum khultah, namun pendapat yang kuat dalam mazhab al-Shāfi' $\overline{1}$ ialah niat tidak disyaratkan. ${ }^{20}$ Justeru, apabila sahaja wang atau harta zakat disimpan dalam tempat atau akaun bersama, maka ia termasuk dalam harta khultah walaupun penyimpan mungkin tidak pernah meniatkan begitu semasa mula ia menyimpan atau membuka akaun simpanan tersebut atau mula melabur dalam satu dana pelaburan.

19 Shams al-Dīn Muhammad bin Aḥmad al-Sharbinī, Mughnī al-Muhtāj ila Ma 'rifatī Ma 'ānī Alfāz al-Minḥāj, vol. 2, 79, al-Ramlī; Nihāyah al-Muhtāj, vol. 3, 62; alJuwaynī, Nihāyah al-Mațlab, vol. 3, 147-148; al-Nawawī; al-Rawdah al-Ṭālibìn, vol. 2, 172. Ini juga adalah salah satu pendapat mazhab al-Hanbalī. Lihat 'Abd Allāh bin Aḥmad bin Qudāmah, al-Mughnī wa Yalīhi al-Syarḥ al-Kabīr, vol. 2, 490.

Adapun selain dari binatang ternakan, terdapat empat pandangan dalam mazhab Shāfiłin:

- Pendapat (pertama) yang yang lebih kuat (al-Azhār) dalam mazhab: khultah juga diambil kira dalam buah-buahan, tanaman, wang dan barangan perniagaan

- Pendapat (kedua) lama Imam Shāfi'ī (qawl qadīm): Khulțah hanya diambil kira pada binatang ternakan sahaja)

- Pendapat ketiga: khultah hanya diambil kira pada harta yang dikongsikan pemilikan melalui khulțah syirkah dan bukan khulțah al-jiwār

- Pendapat keempat: adanya khultah al-Jiwār dan al-Shirkah pada tanaman dan buah-buahan, dan khultah al-Shirkah hanya pada matawang dan perniagaan sahaja

Lihat al-Juwayn̄̄, Nihāyah al-Mațlab, vol. 3, 156; al-Nawawī, al-Majmu'Syarh al-Muhazzab, vol. 5, 429; al-Nawāwī, Rawdah al-Ṭālibīn, vol. 2, 172-173; Shams al-Dīn Muḥammad bin Aḥmad al-Sharbin̄̄, Mughn̄̄ al-Muḥtāj ila Ma'rifatī Ma 'ānī Alfäz al-Minhāaj, vol. 2, 82.

20 Dalam soal ini terdapat dua pendapat iaitu pendapat yang Așah mengatakan tidak disyaratkan niat untuk menjadikan sesuatu harta itu sebagai harta yang tertakluk kepada hukum khultah, dan pendapat bertentangan dengan pendapat yang Așah mengatakan bahawa disyaratkan niat. Shams al-Dīn Muhammad bin Ahmad alSharbin̄̄, Mughnī al-Muhtāj ila Ma 'rifatī Ma'ānī Alfāz al-Minḥāj, vol. 2, 81. Penulis berpendapat bahawa pendapat yang paling kuat ialah pendapat yang $A s ̦ a h$, kerana niat bukanlah perkara yang memberi kesan kepada percampuran harta. 


\section{b) Mazhab Ḥanafī dan Sebahagian Ulama}

Khulțh tidak memberi kesan kepada pengiraan zakat bahkan setiap pemilik harta mempunyai niṣāb yang berasingan. ${ }^{21}$

Mereka berhujah dengan hadis bahawa Nabi SAW telah bersabda:

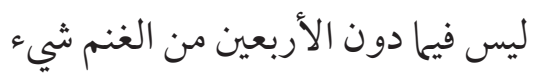

"Tidak dikenakan zakat ke atas binatang ternakan (kambing) yang kurang dari 40 ekor..." 22

Apa yang dapat difahami dari hadis ini ialah Nabi SAW menafikan wajibnya zakat ke atas kurang dari 40 ekor secara mutlak sama ada dalam keadaan berkongsi atau dalam keadaan berasingan, justeru syarat wajib bagi keduanya adalah cukup niṣāb (40 ekor) bagi setiap pemilik harta.

Juga hadis-hadis yang menerangkan berkenaan zakat secara umumnya mensyaratkan bahawa zakat tidak dikenakan jika jumlah bintang ternakan kurang dari yang sepatutnya. Antara hadis-hadis tersebut ialah hadis:

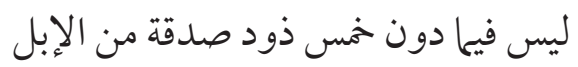

“...tiada bagi 5 ekor unta yang berumur 3-10 tahun itu zakat.. " 23

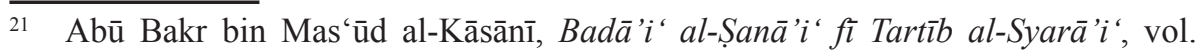
2, ed. Sheikh 'Alī Muḥammad Mu'awwaḍ, Sheikh 'Adil Muhammad 'Abd alMawjūd (Beirūt: Dār al-Kutub al-'Ilmiyyah, cetakan ke-2, 2003), 433-435; Imam Malik dalam soal zakat emas dan perak. Lihat Ibn al-Rusyd, Bidāyah al-Mujtahid, 1: 218 .

22 Sahịh Ibn Khuzaymah, "Kitāb al-Zakāt, Jimā' Abwāb Șadaqah al-Mawāshī min al-Ibil wa al-Baqar wa al-Ghanam: Bāb al-Dalīl 'alā Anna al-Șadaqah Lā Tajib Fīmā Dūna Khams Min al-Ibil wa lā Fīmā Dūna al-Arba‘īn min al-Ghaman”; alBukhārī, Șaḥịh al-Bukhārī, "Kitāb al-Zakāt, Bāb Zakāt al-Ghanam," hadis no. 1386, al-Tirmidhī, Sunan al-Tirmidhī, vol. 3, 8, "Kitāb al-Zakāt, Bāb Ma Jā' fī̄ Zakāt al-Ibil wa al-Ghanam," hadis no. 621.

23 al-Bukhārī, Șah̄ịh al-Bukhārī, 'Bab Zakāt al-Ghanam,' hadis no. 1386, al-Tirmidhī, Sunan al-Tirmidhī, "Kitab al-Zakāt, Bāb Ma Jā' fì Zakāt al-Ibil wa al-Ghanam," hadis no. 621; Shihāb al-Dīn Aḥmad bin 'Alī al-'Asqalān̄̄, Fatḥ al-Bārī Syarạ̣ Șahịh Bukhārī, vol. 3, 378, "Kitāb al-Zakāt: Laysa Fīmā Dūna Khams Dhawd Sadaqah," hadis no. 1327. 
Hadis ini menunjukkan sempurna niṣāb bagi kedua-dua orang yang berkongsi adalah syarat wajib zakat. ${ }^{24}$ Mereka juga berhujah bahawa yang dimaksudkan dengan "himpun" dan "pisah" dalam hadis yang diriwayatkan oleh Anas RA yang digunakan oleh jumhur ulama sebagai hujah ialah, himpun dan pisah pada hak pemilikan dan bukannya himpun dan pisah pada tempat, sama ada tempat tinggal mahupun tempat makan. Justeru, sesiapa yang memiliki 80 ekor kambing sebagai contoh, dia tidak perlu mengasingkannya di dua tempat untuk menjadikan dua niṣa $b$, dan dia juga tidak perlu untuk menghimpunkan empat puluh ekor kambing yang duduk berasingan di tempat yang berbeza untuk mencukupkan satu niṣa $b^{25}$

\section{Pendapat Yang Kuat}

Pendapat yang lebih kuat adalah pendapat yang pertama yang mengatakan bahawa khulțah memberi kesan kepada pengiraan niṣa $b$ zakat, dengan maksud bahawa harta yang bercampur/khultah akan dikira sebagai satu $n i s ̧ \bar{a} b$, yang tertakluk kepada hukum zakat. ${ }^{26}$ Juga pendapat yang mengatakan bahawa khultah juga terpakai kepada harta selain dari binatang ternakan. Inilah pendapat yang telah diputuskan oleh Majmā' Fiqh al-Islāmī al-Dawlī, Majlis Fatwa Kebangsaan, Persidangan Zakat Antarabangsa, ulama-ulama kontemporari dan sebagainya. ${ }^{27}$

24 Jika diperhatikan, kemungkinan besar sebab mazhab Hanafĩ menolak hadis-hadis yang berkaitan khultah adalah kerana ia bertentangan dengan kaedah ușūl mazhab mereka iaitu mereka berpandangan bahawa qiyās jali atau kaedah-kaedah ușūl yang umum tidak boleh dikhususkan oleh hadis $A h \bar{a} d$, dan dalam konteks zakat di sini, qiyās jalī ialah kewajipan membayar zakat secara umum apabila cukup nișāb bagi setiap individu, dan hadis Ahād pula ialah hadis riwayat Anas (hadis bab). Bagi mereka, harta yang bercampur-campur (khultah) yang telah mencapai nisab dikira masih belum mencapai syarat zakat dari segi niṣa $b$ kerana ia dimiliki oleh beberapa orang, sedangkan nișāb zakat adalah berdasarkan pemilikan individu tanpa dicampurkan dengan pemilikan orang lain, dan ini juga dikatakan salah satu pendapat Imam Mālik al-Zanjān̄i, Takhrīj al-Furū', 363, Ibn al-Sam‘ān̄i, alQawāti 'al-Adillah, vol. 2, 365, 366.

25 Rujuk perdebatan antara mazhab al-Shāfi'ī dan mazhab Ḥanafĩ dalam soal ini alMāwardī, al-Hī̄wì al-Kabīr, vol. 4, 94-97.

26 Walaupun mungkin ada pemegang saham yang tidak mencukupi niṣāb individu.

27 Majmā' Fiqhī al-Islāmī al-Dawlī, 'Zakat Saham dalam Syarikat,' http://www. fiqhacademy.org.sa/qrarat/4-3.htm, dicapai 13 Ogos 2014; Majlis Fatwa Kebangsaan, 'Zakat Ke atas Syarikat,' http://www.e-fatwa.gov.my/fatwakebangsaan/zakat-ke-atas-syarikat, dicapai 13 Ogos 2014; Azman Mohd Noor \& Muhamad Nasir Haron, 'Imposing Zakāt on Legal Entities and Its Applications 


\section{APLIKASI SEMASA KHULTTH DAN KESANNYA DALAM PENGIRAAN ZAKAT}

Dengan menganalisa pendapat dalam mazhab al-Shāfi'ī sepertimana yang telah dibincangkan sebelum ini dan membandingkannya dengan apa yang wujud dalam sistem kewangan Islam moden, jelas bahawa simpanan yang di buat di bank-bank, dana-dana pelaburan, instrument kewangan moden seperti $s u k \bar{u} k$, produk-produk perbendaharaan dan sebagainya, ia termasuk dalam khultah kerana wujudnya percampuran harta di samping ianya diuruskan oleh satu pihak. Justeru, ia menepati konsep khultah dan ia termasuk dalam khultah al-syuyu ' atau khultah shirkah/isytirā ${ }^{28}$ dan setiap pemilikan adalah dikira berdasarkan pemilikan bersama berdasarkan nisbah pegangan.

Walaupun khultah wujud dalam harta-harta yang disebutkan di atas, namun dari segi praktis semasa, khultah tidak diamalkan sepenuhnya sebagaimana yang dibincangkan oleh para ulama, bahkan hanya sebahagian sahaja amalan pengiraan dan kutipan zakat semasa dibuat berdasarkan pengiraan khultah dan sebahagian lagi tidak mengambil kira konsep khultah.

Jadual di bawah menunjukkan amalan semasa kutipan zakat bagi hartaharta khultah:

in Islamic Financial Institutions,' 3; Yūsuf al-Qaraḍāwī, Fiqh al-Zakāt, vol. 2, 258; Qurrah Daghi, 'Zakāt Ashum,' http://www.qaradaghi.com/portal/ index.php?option $=$ com_content $\&$ view $=$ article $\& i d=492: 2009-07-12-10-38$ 45\&catid=75:2009-07-12-10-33-29\&Itemid=13, dicapai 13 Ogos 2014. Dalam soal wang kertas, ia juga terpakai berdasarkan qiyās kepada emas dan perak kerana 'illah yang sama yang terpakai pada emas dan perak. Kementerian Waqaf dan Hal Ehwal Islam Kuwait, Mawsū'ah Fiqhiyyah Kuwaitiyah, vol. 19 (Kuwait: Kementerian Waqaf dan Hal Ehwal Islam. t.t.), 228; Lembaga Zakat Selangor, 'Zakat Perniagaan,' http://www.e-zakat.com.my/zakat-harta/zakat-kwsp/, dicapai 13 Ogos 2014.

28 Namun dari aspek lain boleh juga dikatakan bahawa khultah di antara mereka adalah khultah al-jiwār memandangkan bahawa dalam produk deposit dan pelaburan, akad adalah di antara pelanggan secara individu dan bank, bukan di antara para pelanggan (syuyu') dan bank. 
Jadual 1: Aplikasi Khultah dalam Pembayaran Zakat Semasa

\begin{tabular}{|c|c|c|c|c|}
\hline No. & $\begin{array}{c}\text { Jenis Simpanan/ } \\
\text { Syarikat }\end{array}$ & Jenis Pelaburan & Jenis Khultah & $\begin{array}{c}\text { Hukum Zakat/ } \\
\text { Nișāb }\end{array}$ \\
\hline 1. & Tabung Haji & Wadī'ah & al-Jiwār/Syuyū' & Zakat Khultah \\
\hline 2. & $\begin{array}{l}\text { Pelaburan Hartanah } \\
\text { Islam (i-REIT) }\end{array}$ & Wakālah & al-Jiwār/Syuyū' & Zakat Individu \\
\hline 3. & $\begin{array}{l}\text { Unit Amanah (Unit } \\
\text { Trust) }\end{array}$ & Wakālah & al-Jiwār/Syuyū' & Zakat Individu \\
\hline 4. & Akaun Simpanan & $\begin{array}{l}\text { Wadī'ah/ } \\
\text { Wakālah/Tat } \\
\text { warruq }\end{array}$ & al-Jiwar/Syuyū' & Zakat Individu \\
\hline 5. & $\begin{array}{l}\text { Akaun Simpanan } \\
\text { Bersama (Joint Ac- } \\
\text { count) }\end{array}$ & $\begin{array}{l}\text { Wadīah/ } \\
\text { Wakālah/Tat } \\
\text { warruq }\end{array}$ & al-Jiwār/Syuyū' & $\begin{array}{l}\text { Zakat Individu/ } \\
\text { Zakat Khulțah }\end{array}$ \\
\hline 6. & Akaun Pelaburan & $\begin{array}{l}\text { Muḍ̄arabah/ } \\
\text { Wakālah }\end{array}$ & al-Syuyū' & $\begin{array}{l}\text { Zakat Khultah/ } \\
\text { Zakat Individu }\end{array}$ \\
\hline 7. & $\begin{array}{l}\text { Akaun Pelaburan } \\
\text { Emas }\end{array}$ & $\begin{array}{l}\text { Wakālah/ } \\
\text { Wadī'ah }\end{array}$ & al-Syuyū' & Zakat Individu \\
\hline 8. & $\begin{array}{l}\text { Akaun Pelaburan } \\
\text { Emas Bersama }\end{array}$ & $\begin{array}{l}\text { Wakālah/ } \\
\text { Wadī'ah }\end{array}$ & al-Syuyū' & Zakat Individu \\
\hline 9. & Akaun Semasa & $\begin{array}{l}\text { Pinjaman/ } \\
\text { Muḍārabah/ } \\
\text { Wakālah }\end{array}$ & al-Syиyū' & Zakat Individu \\
\hline 10. & $\begin{array}{l}\text { Saham Syarikat } \\
\text { Senaraian Awam }\end{array}$ & Shirkah & al-Syuyū' & Zakat Individu \\
\hline 11. & $\begin{array}{l}\text { Syarikat Perniagaan } \\
\text { Persendirian (Pri- } \\
\text { vate Company) }\end{array}$ & Shirkah & al-Syиyū' & Zakat Khultah \\
\hline 12. & $\begin{array}{l}\text { Syarikat Senara- } \\
\text { ian Awam (Public } \\
\text { Listed Company) }\end{array}$ & Shirkah & al-Syuyū' & Zakat Khultah \\
\hline
\end{tabular}




\begin{tabular}{ccllc}
\hline No. & $\begin{array}{c}\text { Jenis Simpanan/ } \\
\text { Syarikat }\end{array}$ & Jenis Pelaburan & Jenis Khultah & $\begin{array}{c}\text { Hukum Zakat/ } \\
\text { Nișāab }\end{array}$ \\
\hline 13. & $\begin{array}{l}\text { Simpanan Takaful } \\
\text { (Tabung Peserta) }\end{array}$ & $\begin{array}{l}\text { Wakālah/ } \\
\text { Muḍārabah }\end{array}$ & al-Syuyū & Zakat Individu \\
\hline
\end{tabular}

Sumber: Tabung Haji, Lembaga Zakat Selangor. ${ }^{29}$

\section{ANALISA APLIKASI KHULTAH DALAM PENGIRAAN DAN PEMBAYARAN ZAKAT SEMASA}

Jika diperhatikan jadual 1, walaupun jelas khultah telah wujud bagi harta-harta yang disebutkan di atas namun wujud ketidakseragaman dari segi pengiraan dan pembayaran zakat. Ini kerana hanya sebahagian sahaja amalan semasa

29 (i) Tabung Haji: Tabung Haji, 'Simpanan dengan Jaminan,' http://www. tabunghaji.gov.my/simpanan-dengan-jaminan, dicapai pada 14 Januari 2017. Namun yang menimbulkan kemusykilan, pihak Tabung Haji mengisytiharkan dividen, dan dividen sebagaimana dimaklumi imbuhan yang diberikan kepada pemegang saham bukan untuk wadī'ah/qard. Lihat definisi dividen, Investopedia, 'Dividend,' http://www.investopedia.com/terms/d/dividend.asp, dicapai 13 Ogos 2014; Majlis Fatwa Kebangsaan, 'Pembayaran Zakat oleh Tabung Haji,' http:// www.e-fatwa.gov.my/fatwa-kebangsaan/pembayaran-zakat-oleh-tabung-haji, dicapai 13 Ogos 2014.

(ii) Pelaburan Hartanah Islam (i-REIT): Lembaga Zakat Selangor, 'Kalkulator Zakat Saham,' http://www.e-zakat.com.my/kalkulator-zakat/zakat-saham/, dicapai 13 Ogos 2014.

(iii) Unit Amanah (Unit Trust): Lembaga Zakat Selangor, 'Kalkulator Zakat Saham,' http://www.e-zakat.com.my/kalkulator-zakat/zakat-saham/, dicapai 13 Ogos 2014.

(iv) Akaun Simpanan: Lembaga Zakat Selangor, 'Kalkulator Zakat Saham,' http://www.e-zakat.com.my/kalkulator-zakat/zakat-saham/, dicapai 13 Ogos 2014.

(v) Akaun Simpanan Bersama (Joint Account): Lembaga Zakat Selangor, 'Kalkulator Zakat Saham,' http://www.e-zakat.com.my/kalkulator-zakat/zakatsaham/, dicapai 13 Ogos 2014.

(vi) Akaun Pelaburan: Bagi akaun pelaburan di bank-bank, pihak berkuasa zakat tidak menyebutkan secara khusus sama ada ia terletak di bawah zakat simpanan atau zakat pelaburan. Namun, ia sepatutnya dikira berdasarkan zakat saham, kerana antara lain ianya adalah pelaburan. Bahkan akta terbaru kewangan Islam (IFSA) 2013 jelas membezakan antara pelaburan dan simpanan. Lihat 'Islamic Financial Services Act 2013,' http://www.bnm.gov.my/documents/act/en_ifsa. pdf, dicapai pada 13 Ogos 2014. 
mengaplikasikan khultah dalam pengiraan dan pembayaran zakat sementara sebahagian lagi tidak menggunakan konsep khultah. Antara isu berkaitan amalan pengiraan zakat semasa yang dilihat tidak selari dengan konsep khultah yang sedang dibincangkan di sini ialah:

\section{a) Isu Pertama: Khultah Diamalkan di Tabung Haji dan Syarikat Perniagaan Sahaja}

Dari segi amalan pengiraan zakat semasa sama ada ia berdasarkan konsep khultah ataupun tidak, hanya beberapa institusi sahaja yang membuat kiraan zakat menggunakan konsep khultah seperti Tabung Haji yang membayarkan zakat bagi pihak penyimpan berdasarkan pengiraan satu akaun dan satu niṣăb, ${ }^{30}$

(vii) Akaun Pelaburan Emas: Lembaga Zakat Selangor, 'Kalkulator Zakat Saham', http://www.e-zakat.com.my/kalkulator-zakat/zakat-emas-perak/, dicapai 13 Ogos 2014.

(viii) Akaun Pelaburan Emas Bersama: Lembaga Zakat Selangor, 'Kalkulator Zakat Saham', http://www.e-zakat.com.my/kalkulator-zakat/zakat-emas-perak/, dicapai 13 Ogos 2014.

(ix) Akaun Semasa: Pusat Pungutan Zakat, 'Zakat Wang Simpanan,' http://www. zakat.com.my/index.php?option $=$ com_content\&view $=$ article \&id=75\&Itemid $=81$ \&lang=ms, dicapai 13 Ogos 2014.

(x) Saham Syarikat Senaraian Awam: Lembaga Zakat Selangor, 'Kalkulator Zakat Saham', http://www.e-zakat.com.my/kalkulator-zakat/zakat-emas-perak/, dicapai 13 Ogos 2014.

(xi) Syarikat Perniagaan Persendirian (Private Company): Lembaga Zakat Selangor, 'Kalkulator Zakat Saham', http://www.e-zakat.com.my/kalkulatorzakat/zakat-emas-perak/, dicapai 13 Ogos 2014. Difahami dari fatwa ini dalam isu khultah ialah zakat perniagaan secara umum, baik pemiliknya adalah tunggal mahupun pemiliknya adalah lebih dari seorang. Tiada isu khultah bagi pemilik tunggal. Namun bagi pemilik bersama, di sana khultah terpakai sebagaimana fatwa yang telah dikeluarkan Majlis Fatwa Kebangsaan, Zakat Ke atas Syarikat, 'Zakat Kumpulan Wang Simpanan Pekerja KWSP', http://www.e-fatwa.gov.my/ fatwa-kebangsaan/zakat-ke-atas-syarikat, dicapai 13 Ogos 2014.

(xii) Syarikat Senaraian Awam (Public Listed Company): Lembaga Zakat Selangor, 'Kalkulator Zakat Saham', http://www.e-zakat.com.my/kalkulatorzakat/zakat-emas-perak/, dicapai 13 Ogos 2014. Difahami dari fatwa ini dalam isu khultah ialah zakat perniagaan secara umum, baik pemiliknya adalah tunggal mahupun pemiliknya adalah lebih dari seorang. Bagi pemilik tunggal maka ianya tiada isu khulțah, namun bagi pemilik bersama maka di sana khulțah terpakai sebagaimana fatwa yang telah dikeluarkan Majlis Fatwa Kebangsaan. Lihat Zakat Ke atas Syarikat, 'Zakat Kumpulan Wang Simpanan Pekerja KWSP', http:// www.e-fatwa.gov.my/fatwa-kebangsaan/zakat-ke-atas-syarikat, dicapai 13 Ogos 2014 
juga syarikat-syarikat perniagaan sama ada berstatus awam atau swasta. Ini bermaksud bagi Tabung Haji dan syarikat-syarikat seperti yang disebutkan di atas, walaupun ia dimiliki oleh dua orang atau lebih, namun dari segi zakat, akaun syarikat tetap akan dikira sebagai satu niṣāb dan satu hawl, dan darinya akan dikira zakat berdasarkan pengiraan khultah. ${ }^{31}$

Selain dari Tabung Haji dan syarikat-syarikat yang membayar zakat berdasarkan konsep khultah, wujud ketidak seragaman terutama bagi zakat ke atas akaun-akaun simpanan di bank-bank, dana-dana dan instrumen pelaburan semasa. Dalam kebanyakan situasi, individu sendiri yang akan membayar zakat bagi simpanan atau pelaburan mereka. Walaupun dari satu sudut memang sudah menjadi tanggungjawab mereka membayarkan zakat ke atas harta-harta yang mereka miliki, ${ }^{32}$ namun dari aspek yang lain pula, apabila individu sendiri yang membayar zakat bagi wang simpanan mereka maka timbul isu Syariah dari segi pengiraan dan jumlah. Ini kerana mereka akan membuat pengiraan berdasarkan niṣāb dan hawl pemilikan individu sedangkan sepatutnya ia

(xiii) Simpanan Takaful (Tabung Peserta): Lembaga Zakat Selangor, 'Zakat Takaful', http://www.zakatselangor.com.my/jenis-jenis-zakat/zakat-harta/zakattakaful/, dicapai pada 3 Januari 2017.

30 Tabung Haji, 'Statistik 5 Tahun Pembayaran Zakat,' http://www.tabunghaji. gov.my/web/guest/zakat, dicapai 13 Ogos 2014; Majlis Fatwa Kebangsaan, 'Pembayaran Zakat oleh Tabung Haji,' http://www.e-fatwa.gov.my/fatwakebangsaan/pembayaran-zakat-oleh-tabung-haji, dicapai 13 Ogos 2014.

31 Majlis Fatwa Kebangsaan, 'Zakat Ke Atas Syarikat,' http://www.e-fatwa.gov.my/ fatwa-kebangsaan/zakat-ke-atas-syarikat, dicapai 13 Ogos 2014. Bagi Syarikat Awam Tersenarai (Public Listed Company/PLC), apa yang difahami dari fatwa yang ada ialah bahawa ianya tidak mengamalkan konsep khultah bagi syarikat saham yang tidak membayar zakat. Lihat Lembaga Zakat Selangor, 'Zakat Saham,' http://www.e-zakat.com.my/zakat-harta/zakat-saham/, http://www.zakat. com.my/en/zakat-saham.html, dicapai 13 Ogos 2014.

32 Ini kerana dalam soal zakat, berdasarkan pandangan kebanyakan ulama, dari segi pengiraan, akaun akan dikira sebagai satu, namun dari segi kewajipan membayar zakat, ianya tetap kewajipan individu, yang boleh diwakilkan kepada syarikat untuk membayarnya bagi pihak pemegang saham, pelabur atau pendeposit atau penyimpan. Ini adalah berdasarkan keputusan Majmā' Fiqh al-Dawlī, AAOIFI dan lain-lain. Namun bagi sebahagian ulama, antaranya ialah Majlis Fatwa Kebangsaan, Muḥy al-Dīn Qurra Daghi dan lain-lain, kewajipan membayar zakat adalah terletak di atas syarikat itu sendiri di atas dasar ianya adalah entiti berasingan dari pemilik saham berdasarkan konsep syakhșiyyah i'tibāriyah. Lihat Said Bouheraoua, 'Zakah Obligations On Islamic Financial Institutions,' ISRA Research Paper, 34 (2012): 9. 
dikira berdasarkan pengiraan nișāb dan hawl dana dan akaun tersebut secara kolektif. Ini kerana khultah telah wujud kerana wang simpanan yang dimiliki oleh penyimpan tersebut bercampur dengan wang dari penyimpan-penyimpan lain. Bagi seorang yang memiliki sejumlah RM1,000 ringgit dalam akaun simpanan mereka sebagai contoh, berdasarkan pengiraan zakat individu, ia tidak dikenakan zakat kerana tidak mencapai nișāb yang merupakan syarat kewajipan zakat, namun jika berdasarkan konsep khultah, ia dikenakan zakat kerana dalam khultah, bukan pengiraan individu yang menjadi penentu, tetapi $n i s ̧ \bar{a} b$ dan pengiraan akaun dan dana yang diuruskan secara kolektif yang diambil kira.

Begitu juga bagi pihak pengendali akaun-akaun ini pula(bank), mereka tidak membayarkan zakat bagi pendeposit mereka, bahkan mereka menyerahkan urusan pembayaran zakat kepada pendeposit sendiri untuk menyelesaikannya. Hatta, bagi bank yang menyediakan perkhidmatan membayarkan zakat bagi pihak pendeposit mereka sekalipun, mereka hanya membayarkan zakat berdasarkan pengiraan zakat individu sahaja dan tidak mengambil kira khultah bagi wang yang terdapat dalam akaun yang mereka uruskan.

Begitu juga bagi zakat emas dan perak, bagi akaun pelaburan Islam berasaskan emas, fatwa menyebutkan bahawa zakat dikenakan jika ia melebihi $n i s ̣ \bar{a} b$ emas dan perak. ${ }^{33}$ Fatwa ini jika merujuk kepada niṣāb emas secara umum, maka tiada isu yang timbul. Namun jika ia difahami dalam konteks perbankan, maka isu Syariah yang timbul ialah sebagaimana dimaklumi, emas disimpan dan dijaga di satu tempat yang sama dengan pemilik-pemilik lain dan ia menepati konsep harta khultah. Namun dari segi pengiraan zakat semasa, percampuran ini tidak diambil kira bahkan setiap pemilik akaun secara individu akan membayar zakatnya sendiri jika emas yang ia miliki telah mencapai niṣābnya tanpa mengambil kira emas yang dimiliki oleh orang lain yang disimpan bersama dengan emasnya, dan ini jelas menunjukkan bahawa khultah juga tidak terpakai dalam akaun pelaburan/simpanan emas kerana secara logiknya jika khulțah terpakai maka niṣāb individu sudah tidak lagi relevan.

33 Lembaga Zakat Selangor, 'Zakat Emas Perak,' http://www.e-zakat.com.my/zakatharta/zakat-emas-perak/, dicapai 13 Ogos 2014; Zaharuddin Abdul Rahman, 'Hukum Akaun Pelaburan Emas di Malaysia,' http://zaharuddin.net/pelaburan-\&perniagaan/764-hukum-akaun-pelaburan-emas-di-bank-malaysia.html, dicapai 13 Ogos 2014. 


\section{b) Isu Kedua: Mencampurkan Harta dari Beberapa Akaun Untuk Mencukupkan Kadar Zakat}

Antara isu yang berkaitan dengan khultah juga ialah amalan semasa yang mencampurkan harta (duit) dari akaun-akaun yang berlainan untuk mencukupkan niṣāb zakat wang simpanan/emas/perak yang mana ia ditetapkan oleh kebanyakan badan pengutip zakat. ${ }^{34}$ Mereka mengatakan bahawa jika simpanan dari akaun bank X tidak mencapai niṣāb sebagai contoh, maka ia harus dicampur dengan simpanan dari akaun lain, atau ditambah lagi dengan tunai yang berada di tangan untuk mencukupkan nișāb individu, dan apabila jumlah keseluruhan sudah sempurna niṣāb dan hawl, maka barulah harta tersebut dikenakan zakat. ${ }^{35}$

Praktis sebegini jika diperhatikan mungkin boleh diperhalusi lagi berdasarkan hujah-hujah di bawah:

1. Tidak bertepatan dengan maksud hadis dan konsep khultah itu sendiri ${ }^{36}$ iaitu jelas dinyatakan bahawa Nabi SAW bersabda:

$$
\text { لا يجمع بين مفترق ولا يفرق بين ججتمع خشية الصدقة }
$$

"Tidak dihimpunkan (harta zakat) yang terpisah dan tidak dipisahkan (harta zakat) yang terhimpun untuk mengelakkan dari (membayar) zakat..." 37

Walaupun ulama telah bersepakat bahawa jika seseorang itu mempunyai harta di beberapa tempat maka ia perlu dicampurkan untuk pengiraan zakat, ${ }^{38}$ namun ianya hanya terpakai bagi wang atau harta-harta yang tidak bercampur antara beberapa pemilik, namun jika harta telah bercampur antara beberapa pemilik sebagaimana halnya wang-wang yang disimpan

34 Lembaga Zakat Selangor, 'Zakat Wang Simpanan', http://www.e-zakat.com. my/zakat-harta/zakat-wang-simpanan/, dicapai 13 Ogos 2014; Pusat Kutipan Zakat Pahang, 'Kalkulator Zakat Simpanan', http://www.zakatpahang.my/v2/ KhidmatKalkulatorZakatSimpanan.aspx, dicapai 13 Ogos 2014.

35 Lembaga Zakat Selangor, 'Zakat Wang Simpanan', http://www.e-zakat.com. my/zakat-harta/zakat-wang-simpanan/, dicapai 13 Ogos 2014; Pusat Kutipan Zakat Pahang, 'Kalkulator Zakat Simpanan', http://www.zakatpahang.my/v2/ KhidmatKalkulatorZakatSimpanan.aspx, dicapai 13 Ogos 2014.

36 Shihāb al-Dīn Mahmūd bin Aḥmad al-Zanjānī, Takhrīj al-Furū' 'alā al-Ușūl, 115.

37 Ibn Ḥajar al-'Asqalān̄i, Fath al-Bārī, vol. 3, 368, "Kitāb al-Zakāt: Bāb Lā Yujma" Bayna Mutafarriq wa la Yufarraq Bayna Mujtami‘ in," hadis no. 1419, 1420.

38 Shihāb al-Dīn Aḥmad bin 'Alī al-'Asqalānī, Fatḥ al-Bārī Syaraḥ Ṣaḥịh Bukhārī, vol. 3,368 . 
bank-bank pada hari ini maka wujudlah khultah. Khulțh seolah-olah telah mengkhususkan keumuman mencampurkan harta di tempat yang berbeza untuk pengiraan zakat. ${ }^{39}$

2. Maksud dan 'illah kenapa dikenakan zakat ke atas harta khultah ialah wujudnya khifyah al-mu'nah (keringanan) dalam soal pengurusan harta ${ }^{40}$ dan sewajarnya zakat dikenakan ke atas harta yang telah digabungkan, kerana telah ada keringanan kepada pemilik harta dalam soal pengurusan harta mereka.

3. Maksud pendapat fuqaha yang mewajibkan penggabungan ini adalah jika adanya harta yang tidak bercampur dan ada yang bercampur, namun melihat kepada situasi pada hari ini, wang pendeposit-pendeposit telah bercampur antara satu sama lain, maka setiap akaun yang diuruskan oleh pihak bank itu telah ada khultah masing-masing.

4. Selain dari itu juga, dari satu sudut, impak kepada pengiraan yang tidak berdasarkan pengiraan khultah ini ialah ia akan boleh mengurangkan jumlah pembayar dan hasil kutipan zakat, dan seterusnya mengurangkan sumber bantuan yang boleh disalurkan kepada asnaf zakat.

Jelas berdasarkan apa yang telah dibincangkan di atas bahawa mencampurkan harta-harta yang berada di beberapa tempat yang mana telah wujud khultahnya masing-masing adalah bertentangan dengan apa yang telah dibincangkan oleh para fuqaha mazhab al-Shāfi 'ī berkaitan konsep khulțh. Sewajarnya zakat dikenakan ke atas setiap harta yang telah mememenuhi definisi konsep khultah tanpa perlu dicampurkan dengan harta-harta di tempat lain semata-mata untuk mencukupkan niṣāb zakat seseorang pemilik harta.

\section{HALANGAN DALAM PENGIRAAN DAN KUTIPAN ZAKAT BERDASARKAN KONSEP KHULTAH DAN PENYELESAIANNYA}

\section{a) Akaun Berbeza Tempoh}

Antara punca khultah tidak diamalkan secara meluas terutama dalam konteks akaun perbankan dan pelaburan Islam adalah akaun yang berbeza tempoh

39 Namun demikian pendapat yang lebih aṣah dalam mazhab Shāfi‘ī ialah khulțah akan menjadikan kesemua asset menjadi asset khulțah sekalipun sebahagian asset seseorang itu khulțah dan sebahagiannya tidak khultah (atau disimpan sendiriianya dinamakan Khulțah al-Milk). Rujuk 'Abd al-Karīm bin Muḥammad alRāfi'1̄, al- 'Azīz Syarh al-Wajīz, vol. 5, ed. 'Adil 'Abd al-Mawjūd (Beirūt: Dār alKutub al-'Ilmiyyah, 1997), 517-518; al-Nawāwī, al-Majmu', vol. 5, 421.

40 Hannan 'Abd al-Raḥmān Abū Mukh, 'Zakāt al-Syarikāt fi al-Fiqh al-Islamī', 115116. 
waktu ia dibuka, di samping jumlah simpanan semasa ia dibuka tidak mencapai nișāb. Ini kerana syarat khultah ialah ia mesti mencapai hawl dan niṣāb bermula dari tarikh ia dicampurkan. ${ }^{41}$ Jika percampuran itu berlaku pada waktu yang sama, maka tiada masalah. Namun jika ia dibuka dalam waktu yang berbeza, maka khultah untuk tahun tersebut tidak terpakai. Isu ini agak rumit kerana jika mengikut tarikh pembukaan akaun, maka mungkin akan ada berjuta-juta hawl dalam satu bank dan pengurusan dana dan ini sangat menyusahkan pihak bank dan institusi yang menyimpan wang untuk membuat pengiraan zakat bagi penyimpan mereka.

Namun, sebenarnya ia bukanlah masalah besar sehingga diketepikan khultah itu sendiri kerana bagi pemilik akaun bank yang belum mencapai tempoh akaun setahun (hawl), walaupun menurut mazhab Shāfi'ī ia tidak dikenakan zakat, namun untuk memudahkan pengiraan zakat maka apa yang diambil kira adalah kecukupan niṣāb akaun-akaun dan dana-dana. Adapun hawl maka memadailah mengikut hawl institusi kewangan atau pengurus dana itu sahaja, tanpa mensyaratkan sempurnanya hawl bagi setiap penyimpan.

Ini juga yang diamalkan dalam zakat perniagaan yang mana hanya hawl syarikat yang dikira. Adapun hawl bagi setiap pemegang saham, maka ia tidak terpakai. Dalam konteks zakat perniagaan, hawl adalah berdasarkan laporan tahunan (Financial Report) syarikat dan bukan berdasarkan hawl setiap pemilik saham syarikat. Kaedah pengiraan khultah sebegini lebih memudahkan bagi semua pihak, apatah lagi dalam konteks zakat simpanan yang mana bagi penyimpan, wujud kesukaran bagi mereka untuk membuat pengiraan sendiri. Dalam soal ini juga, 'Izz al-Dīn Khawjah ada menyebutkan:

"Pelabur-pelabur(dalam akaun bank/dana pelaburan) membayar zakat mengikut mana-mana hawl dana/akaun bagi mana-mana tahun kewangan yang disebutkan padanya pengiraan zakat, dan ia tidak dikira berdasarkan hawl individu (pelabur), sama

$\overline{41}$ al-Nawāwī, 'al-Majmū',' vol. 5, 416; al-Rāfi'ī, al-'Azīz Sharh al-Wajīz, vol. 3, 517-518. Ini juga adalah pendapat mazhab Hanbalī. Rujuk 'Abd Allāh bin Aḥmad bin Qudāmah, al-Mughn̄̄ wa Yalīhi al-Syarh al-Kabīr, vol. 2, 534. Kata Imam al-Shāfi‘̄i: "dan tidak dikira (harta) dua orang sebagai harta khulțah sehingga berlalu ke atas kedua mereka setahun dari tempoh percampuran, dan jika berlalulah setahun maka dikenakan zakat ke atas mereka satu individu, dan jika tidak cukup setahun harta dicampurkan maka zakat adalah untuk dua orang (berasingan)” al-Shāfi ‘̄i, al-Umm, vol. 1, 234. 
juga bagi pelabur-pelabur yang belum mencapai nișāb secara individu di mana mereka tidak terlepas dari kewajipan zakat..." 42

Jelas dari kenyataan di atas bahawa pengiraan berdasarkan khultah adalah dengan melihat kepada hawl tahun kewangan dana-dana dan akaun dan tidak bergantung kepada pengiraan hawl individu.

\section{b) Cara Pembayaran Zakat Yang Tidak Jelas}

Ini adalah isu yang berkaitan cara pembayaran dan kutipan zakat khulțh iaitu dari segi tanggungjawab pembayaran zakat, ianya adalah tanggungjawab pemilik wang, namun dari segi kutipan ianya adalah tanggungjawab lembagalembaga zakat, dan bukan tanggungjawab pengendali pelaburan Islam atau bank-bank. Sebarang keputusan dalam mengenakan zakat ke atas akaun simpanan atau pelaburan berdasarkan konsep khultah perlu melalui proses perbincangan dengan pihak bank dan pengendali tabung-tabung dahulu. ${ }^{43}$

Namun isu ini boleh di atasi dengan cara pihak institusi zakat melantik bank sebagai amil dalam mengutip zakat bagi akaun-akaun yang dikendalikan mereka. Cara ini juga boleh menjana sumber pendapatan baru bagi bank iaitu melalui bayaran upah dari pusat zakat sebagai amil. Bagi bank konvensional

${ }^{42}$ Kertas kerja Sheikh Ḥassan bin Ghālib Dailah, Zakāt Șanādiq al-Istithmār, Nadwah Zakāt al-Ashum wa al-Ṣanādīq, dipetik dari kitab Zakāt al-Musyarakāt $f i$ al-Ṣanādiq wa al-Isdārāt, 'Izz al-Dīn Khawjah, 69. http://www.iifef.org/node/474. Bahkan dalam soal ini, Qaraḍāwī telah mentarjihkan pendapat al-Shāfi'īyyah yang mengatakan bahawa dalam zakat perniagaan, niṣāb diambil kira di akhir hawl, dan bukan di awalnya. Al-Qaraḍāwī menaqalkan kata-kata Imam al-Shāfi'ī:

فالحول ينعقد على ما دون النصاب، ولا يشترط النصاب إلا في أخر الحول، فإذا بلغ في أخره نصابا، زكاه. "Maka hawl akan bermula bagi harta yang belum mencapai niṣāb, dan tidak disyaratkan sempurnanya nișāb kecuali pada akhir hawl, di mana jika diakhirnya (hawl) telah sempurna nișāb maka zakat hendaklah dibayar..." Yūsuf al-Qarad̄āwī, 'Fiqh al-Zakāh,' http://qaradawi.net/new/ library2/266-2014-01-26-18-46-06/2280, dicapai 13 Ogos 2014.

43 Di sana pernah dianjurkan "Bengkel Zakat Industri Kewangan" yang mana memutuskan bahawa: "Ahli-ahli bengkel telah bersetuju bahawa dalam isu ini, kewajipan membayar zakat adalah di pihak kepada pendepositor itu sendiri dan bukannya bank atau institusi yang menguruskan dana deposit tersebut." Lihat Lembaga Zakat Selangor, 'Bengkel Zakat Industri Kewangan', http://www.ezakat.com.my/terkini/bengkel-zakat-industri-kewangan/, dicapai 13 Ogos 2014. 
pula, mereka juga boleh membuat perkara yang sama, namun zakat hanya dikenakan ke atas simpanan pokok (principal) sahaja. ${ }^{44}$

Bagi menyokong perkara di atas juga, pihak-pihak majlis fatwa juga perlu bergerak aktif dalam mengeluarkan fatwa-fatwa dan ketetapan atau garis panduan yang menekankan kepada kepentingan dan kewajipan pengiraan dan pembayaran zakat berdasarkan konsep khultah. Ini dapat membantu bukan sahaja pihak yang menjalankan tugas mengutip zakat bahkan orang awam juga dapat mengetahui tanggungjawab yang perlu mereka tunaikan ke atas hartaharta yang mereka miliki.

\section{c) Pemilik Akaun Tidak Tertakluk Kepada Zakat}

Antara halangan dalam mengimplementasikan kiraan zakat berdasarkan konsep khultah dalam akaun dan dana-dana pelaburan juga ialah:

\section{(i) Pemilik Yang Bukan Beragama Islam}

Dari segi pembayar zakat, disyaratkan bahawa mereka mestilah beragama Islam. ${ }^{45}$ Bagi bukan Islam, dari segi tuntutan hukum dunia, mereka tidak diwajibkan untuk membayar zakat kerana zakat adalah ibadah, dan mereka bukanlah ahli ibadah. ${ }^{46}$

Berkaitan perkara ini, bagi simpanan di Tabung Haji, tiada masalah dalam soal pembayaran zakat berdasarkan konsep khultah kerana hanya pendeposit yang beragama Islam sahaja yang dibenarkan membuka akaun di Tabung Haji, justeru zakat hanya dibayar dari pemilik yang beragama Islam sahaja.

Namun, bagi zakat akaun simpanan yang diuruskan oleh bank atau danadana pelaburan dan sebagainya, adalah menjadi satu kesukaran bagi pihak bank atau pihak pengurus dana untuk mengenal pasti agama para pendeposit dan pelabur mereka sama ada mereka adalah Islam mahupun tidak. Ini kerana dalam sistem mereka, mereka mungkin tidak mempunyai satu pembahagian

44 AAOIFI menyebutkan bahawa bagi akaun konvensional, hanya kadar simpanan pokok (principal) sahaja yang akan dikenakan zakat, adapun bahagian riba (interest) maka tidak dikenakan zakat. Lihat Accounting and Auditing of Islamic Financial Institution (AAOIFI), Ma'āyir al-Syar'iyyah, 35 (Bahrain: AAOIFI, 2007), 621.

45 MAIWP, 'Zakat Syarikat yang Bercampur-Campur', http://www.zakat.com.my/ fatwa-zakat; al-Qarḍawī, Fiqh al-Zakāt, vol. 1, 125.

46 Muștafā Khin, Muștafā Bugha 'Alī Sharbaj̄̄, Fiqh al-Manhajī 'alā Madhhab alImām al-Shāfi 'ì, vol. 1, 276. 
antara pendeposit yang bukan Islam dan yang Islam. Isu ini juga wujud bagi syarikat-syarikat yang mempunyai akaun di bank-bank Islam, kerana pihak bank tidak mengetahui adakah syarikat-syarikat ini dimiliki oleh orang Islam atau orang bukan Islam.

Isu ini bukanlah isu yang sukar ditangani kerana bank atau pengurus dana boleh mengklasifikasikan pendeposit mereka sama ada mereka adalah Islam atau bukan Islam. Ini boleh dilakukan dengan meminta pendeposit atau pelabur memaklumkan kepada pihak bank tentang agama mereka ketika mana mereka membuka akaun, atau meminta pihak bank memasukkan pilihan agama dalam borang pembukaan akaun mereka. Ini bagi membolehkan mereka mengira zakat berdasarkan khultah, dan hanya mereka yang Muslim sahaja yang dikenakan zakat. Bagi akaun yang dimiliki oleh syarikat pula, jika syarikat 100 peratus dimiliki oleh orang Islam maka tiada masalah, namun bagi syarikat yang dimiliki oleh Islam dan bukan Islam, sama ada mereka memaklumkan kepada pihak bank atau pengurus dana nisbah peratus yang dimiliki oleh pemegang saham yang beragama Islam sahaja, atau memaklumkan bahawa pihak syarikat sendiri yang akan membayar zakat, namun dari segi pengiraan ianya mesti berdasarkan khultah dan bukan berdasarkan pengiraan secara individu/syarikat. Ini kerana harta syarikat telah menjadi harta khultah kerana ia telah bercampur dengan pendeposit lain semasa duit tersebut berada di bawah pengurusan bank dan pengurus dana. ${ }^{47}$

\section{(ii) Pemilik Harta Yang Dikecualikan dari Kewajipan}

Termasuk juga dalam isu ini ialah pemilik akaun yang dikecualikan dari zakat seperti akaun yang dimiliki oleh badan kebajikan, waqaf umum, masjid, surau $^{48}$ dan sebagainya. Ini juga bukan menjadi satu halangan besar kerana pemilik zakat boleh memaklumkan kepada pihak bank, atau pihak bank boleh memasukkan pilihan jenis institusi untuk mereka mendapatkan maklumat berkenaan sama ada institusi tersebut dikenakan zakat ataupun tidak.

\footnotetext{
47 Bagi syarikat yang membayar zakat melalui konsep khultah bagi wang yang mereka miliki dan disimpan di bank-bank sebagainya yang dicadangkan ini, ketika membuat pengiraan zakat syarikat perniagaan, mereka perlu mengeluarkan wang yang berada di bank-bank. Ini kerana tolakan zakat telah dibuat dan sebagaimana yang dimaklumi, zakat tidak dikenakan ke atas harta yang sama sebanyak dua kali.

48 Pusat Pungutan Zakat, 'Apakah pihak duit masjid dan surau juga perlu mengeluarkan zakat', http://www.zakat.com.my/faq., dicapai 4 April 2016; AAOIFI, Ma 'āyìr al-Syari 'iyyah, 35, 3/1/6, 473.
} 
Bagi akaun syarikat-syarikat yang menjalankan perniagaan yang tidak patuh Syariah, mereka tidak dikenakan zakat kerana zakat hanya dikenakan ke atas harta yang halal yang dimiliki oleh tuannya sahaja. ${ }^{49}$ Di sini mungkin timbul kesukaran bagi pihak bank mengasingkan jenis syarikat sebegini dan perkara ini agak sensitif kerana pihak syarikat mungkin tidak mahu menyatakan sama ada aktiviti mereka adalah patuh Syariah atau pun tidak. Ataupun mereka sendiri tidak tahu atau tidak mahu tahu sama ada aktiviti mereka patuh Syariah atau tidak.

Namun dicadangkan supaya dimasukkan pilihan jenis syarikat apabila syarikat membuka akaun, dan bagi mengelakkan masalah penentuan syarikat sama ada patuh Syariah ataupun tidak, pilihan yang dicadangkan dalam borang pembukaan akaun ialah adanya bahagian dalam borang yang menyatakan sama ada syarikat tertakluk kepada zakat atau tidak sahaja, tanpa memperincikan punca tidak membayar zakat.

(iii) Pemilik Harta Beragama Islam Yang Tidak Mahu Membayar Zakat/ Pemilik Harta Yang Bermazhab Hanafĩ Yang Langsung Tidak Menerima Konsep Khultah atau Mazhab Selain dari Mazhab al-Shāfi'ī Yang Menolak Adanya Khultah Selain dari Binatang Ternakan

Mungkin terdapat juga pemilik yang memang tidak mahu membayar zakat, atau tidak mahu membayar zakat melalui bank, atau pemilik harta dan akaun yang bermazhab Hanafĩ dan mazhab lain yang menolak adanya zakat khultah sebagaimana yang difahami oleh mazhab al-Shāfi‘ $\overline{1}$. Bagi pemilik-pemilik harta sepertimana di atas, mereka juga boleh menyatakan dalam borang pembukaan akaun bahawa wang mereka dikecualikan dari zakat khultah. Ini juga tidak menjadi halangan kerana sama ada mereka sendiri membayar zakat, atau tidak membayar langsung zakat, atau berpegang kepada mazhab yang berpandangan tidak dikenakan zakat pada wang atau pada khultah itu sendiri, maka itu terpulang kepada mereka. Apa yang penting ialah pihak bank dan pihak pengurus dana yang menguruskan wang pelanggan mereka membayarkan zakat berdasarkan konsep khultah.

Namun, di sini juga perlu ditekankan bahawa bagi mereka yang tidak tidak menerima pakai pendapat mazhab al-Shāfi‘ dalam soal khultah, sekiranya wang mereka telah mencukupi niṣāb dan hawl individu, maka wajib ke atas mereka mengeluarkan zakat dari wang yang mereka miliki.

49 Yūsuf al-Qaraḍāwī, Fiqh al-Zakāt, vol. 2, 166. 


\section{KESIMPULAN}

Khultah mempunyai potensi besar dalam memajukan kutipan dan pengagihan zakat kepada golongan asnaf. Namun, melihat kepada aplikasi semasa konsep ini, ianya seolah dipinggirkan dan potensinya tidak dioptimumkan sebaik mungkin. Ini kerana berdasarkan apa yang telah dibincangkan dalam penulisan ini, jelas bahawa apa yang diamalkan dalam pengiraan zakat semasa terutama dalam akaun-akaun di bank dan dana-dana pelaburan hanyalah pengiraan zakat secara biasa yang tidak mengambil kira wujudnya khultah. Bahkan dalam perbincangan semasa tentang zakat, tajuk-tajuk perbincangan yang biasa mengambil tempat hanyalah berkaitan dengan harta-harta yang dikenakan zakat, syarat wajib zakat dan kadarnya sahaja sedangkan dalam soal zakat, khultah salah satu tajuk yang diberi penekanan oleh para fuqaha mazhab al-Shāfi' $\overline{1}$, di samping ia juga berfungsi besar dalam menyampaikan maksud syarak dalam zakat iaitu membantu pembayar melaksanakan kewajiban zakat, dan membantu penerima dan mereka yang memerlukannya.

Walaupun telah diadakan bengkel, seminar dan perbincangan tentang zakat akaun simpanan di bank-bank, namun ianya dikira masih tidak memadai dalam menyelesaikan persoalan tentang khultah dan kesannya dalam pembayaran zakat sepertimana yang cuba diutarakan dalam penulisan ini. Justeru, melalui penulisan ini, semua pihak yang terlibat dalam soal zakat diharap dapat duduk bersama membincangkan persoalan berkaitan khultah. Melalui pengamalan konsep khultah dalam pengiraan dan kutipan zakat semasa, diharap ianya dapat memaksimumkan sumber pendapatan bagi institusi kutipan dan agihan zakat. Agensi yang diamanahkan untuk membuat kutipan zakat juga sudah tidak boleh lagi terlalu bergantung kepada sumber sedia ada terutamanya zakat pendapatan sebagai sumber utama. Ini kerana selain ia (zakat pendapatan) adalah terhad, ia juga menimbulkan beberapa isu Syariah. ${ }^{50}$ Lantaran itu mereka mesti menerokai sumber-sumber lain dan antaranya ialah dengan penerokaan

50 Isu utama dalam zakat pendapatan ialah cukupnya hawl, kerana zakat pendapatan tidak mengambil kira hawl bahkan zakat dikenakan sekalipun tidak cukup hawl. Hawl sebenarnya berfungsi sebagai penanda aras sama ada seseorang itu kaya atau miskin. Bagi mereka yang tidak menggunakan harta mereka selama setahun, maka mereka dikira sebagai kaya. Sebaliknya jika harta mereka berada dalam pemilikan tidak sampai setahun, maka mereka sebenarnya tidak wajib membayar zakat. Bahkan mengambil kira kos sara hidup pada hari ini yang sangat tinggi, sedangkan kaedah pengiraan zakat masih ditakuk lama. Maka sewajarnya kaedah pengiraan zakat pendapatan dikaji semula, supaya mengikut kehendak sebenar Syariah dalam kewajipan zakat iaitu, "diambil dari orang kaya dan diberi kepada orang miskin..." Lihat Shihāb al-Dīn Aḥmad bin 'Alī al-'Asqalānī, Fath al-Bārī Syarah Sahịh Bukhārī, vol. 3, 307, hadis no. 1363. 
kutipan zakat berdasarkah pengiraan khultah dalam dana-dana pelaburan, simpanan di bank-bank dan lain-lain lagi. Walaupun wujud cabaran dalam mengaplikasikan konsep khultah ini namun dengan semua pihak yang terlibat dalam isu zakat ini bersama-sama berganding bahu dalam menerokai potensi yang ada pada zakat khultah ini, maka ianya boleh menghasilkan impak yang baik dan seterusnya dapat menyampaikan tujuan zakat sebagaimana yang dituntut oleh syarak.

\section{RUJUKAN}

'Abd al-Karīm bin Muḥammad al-Rāfi'ī, al-'Azīz Syarh al-Wajīz, vol. 5, ed. 'Adil 'Abd al-Mawjūd (Beirūt: Dār al-Kutub al-'Ilmiyyah, 1997).

'Abd al-Mālik bin 'Abd Allāh al-Juwaynī, Niḥāyah al-Mațlah fì Dirāyah alMadhhab, vol. 3 (Jeddah: Dār al-Minhāj, 2007).

'Abd Allāh bin Aḥmad bin Qudāmah, al-Mughnī wa Yalīhi al-Syarḥ al-Kabīr, vol. 2 (Beirūt: Dār al-Kitāb al-'Arabī, t.t.).

Abī Zakariyya Yaḥya bin Syaraf al-Nawāwī, Rawdah al-Ṭālibīn wa 'Umdah al-Muftīn, vol. 2 (Beirūt: Maktab al-Islāmī, 1991).

Abū al-Hassan 'Alī bin Muhammad al-Māwardī, al-Hāwī al-Kabīr, vol. 4 (Beirūt: Dār al-Kutub al-'Ilmiyyah, 1999).

Abū Bakr 'Abd Allāh bin Muḥammad bin Abī Shaybah, Musnad Ibn Abī Shaybah, ed. 'Adīl bin Yūsuf al-Ghazadī, Aḥmad Farīd al-Mazīdī (Riyāụ: Dār al-Wațan, t.t.).

Abū Bakr Aḥmad bin Ḥussīn bin 'Alī Al-Bayhaqī, Sunan al-Kubrāa, vol. 4, ed. Muḥammad 'Abd al-Qādir Ața (Beirūt: Dār al-Kutub al-'Ilmiyyah, 2003).

Abū Bakr bin Mas 'ūd al-Kāsān̄i, Badā'i ' al-Șanā' 'i 'fì Tartīb al-Syarā' 'i', vol. 2, ed. Sheikh 'Alī Muhammad Mu'awwaḍ, Sheikh 'Adil Muhammad 'Abd al-Mawjūd (Beirūt: Dār al-Kutub al-'Ilmiyyah, 2003).

Abū Hamid Muḥammad bin Muḥammad al-Ghazālī, al-Wajīz fì al-Fiqh alShāfi 'ํ, vol. 2, ed. 'Alī Mu'awwad, 'Ad̄̄ 'Abd al-Mawjūd (Beirūt: Dār al-Arqām bin Ab̄̄ al-Arqām, 1997).

Abū Isḥāq Ibrahīm bin 'Alī al-Shirāzī, al-Muhazzab, vol. 1, ed. Muhammad Zuhaylī (Damsyīq: Dār al-Qalam, 1996).

Abū al-Walīd Sulayman bin Khalaf al-Bājī, al-Muntaqā Syarh al-Muwatta', vol. 2 (Mesir: Maṭba'ah al-Sa'ādah, 1332), 136-137.

Abū Zakariya Maḥy al-Dīn bin Sharaf al-Nawawī, al-Majmū' Syarh alMuhazzab, vol. 5 (Jeddah: Maktabah Irshād, t.t.). 
Accounting and Auditing of Islamic Financial Institution, Ma'āyir alSyar 'iyyah (Bahrain: AAOIFI, 2007).

Aḥmad bin al-Shu'ayb al-Nasā'̄', Sunan al-Nasā' '̄, ed. 'Abd Allāh bin 'Abd al-Muḥsīn (Qāhirah: Mu'assasah al-Risālah, 2001).

Aḥmad bin Rusyd Ibn al-Rusyd, Bidāyah al-Mujtahid, dengan Hamish alSabül al-Murshid ilā Bidāyah al-Mujtahid wa al-Nihāyah al-Muqtasid, ed. 'Abd Allāh Abadī (Qāhirah: Dār al-Salam, 1995).

Azman Mohd Noor \& Muhamad Nasir Haron, 'Imposing Zakāt on Legal Entities and its Applications in Islamic Financial Institutions,' http:// www.drazman.net/wp-content/uploads/2013/10/Paper-on-ImposingZakah-on-legal-entities070711.pdf, dicapai pada 14 Julai 2016.

Dār al-Qutn̄̄, 'Alī bin 'Umar, Sunan Dār al-Qutnī, ed. Adil 'Abd al-Mawjūd, 'Alī Muḥammad Mu'awwaḍ (Beirūt: Dār al-Ma'rifah, 2001).

Hannan 'Abd al-Rahmad Abū Mukh, Zakāt al-Syarikāh fì al-Fiqh al-Islāmī ('Ammān: Dār al-Ma'mūn, 2007).

Ibn Faris, Aḥmad bin Faris, Mu 'jam Maqāyis al-Lughah, ed. 'Abd al-Salam Muḥammad Harun (Beirūt: Dār al-Fikr, 1979).

Investopedia, 'Dividen,' http:/www.investopedia.com/terms/d/dividend.asp, dicapai pada 20 Ogos 2016.

Kementerian Waqaf dan Hal Ehwal Islam Kuwait, Mawsü'ah Fiqhiyyah Kuwaitiyah (Kuwait: Kementerian Waqaf dan Hal Ehwal Islam, t.t.).

Lembaga Zakat Selangor(LZS), 'Zakat Pendapatan,'http://www.zakatselangor. com.my/calkulator-zakat/zakat-pendapatan/, dicapai pada 14 Julai 2016.

Lembaga Zakat Selangor, 'Kalkulator Zakat Perniagaan,' http://www. zakatselangor.com.my/calkulator-zakat/zakat-perniagaan/, dicapai pada 9 Julai 2016.

Lembaga Zakat Selangor, 'Kalkulator Zakat Saham,' http://www.e-zakat. com.my/kalkulator-zakat/zakat-saham/, dicapai pada 13 Ogos 2014.

Lembaga Zakat Selangor, 'Kalkulator Zakat Saham,' http://www.e-zakat.com. my/kalkulator-zakat/zakat-emas-perak/, dicapai pada 13 Ogos 2014.

Lembaga Zakat Selangor, 'Kalkulator Zakat Saham,' http://www.e-zakat.com. my/kalkulator-zakat/zakat-emas-perak/, dicapai pada 13 Ogos 2014.

Lembaga Zakat Selangor, 'Zakat Emas Perak,' http://www.e-zakat.com.my/ zakat-harta/zakat-emas-perak/, dicapai pada 13 Ogos 2014.

Lembaga Zakat Selangor, 'Zakat Perniagaan,' http://www.zakatselangor.com. my/jenis-jenis-zakat/zakat-harta/zakat-perniagaan/, dicapai pada 28 Julai 2016. 
Lembaga Zakat Selangor, 'Zakat Pendapatan,' http:/www.zakatselangor. com.my/faq-kutipan-zakat/faq-zakat-pendapatan/, dicapai pada 10 Julai 2016.

Majlis Agama Islam Wilayah Persekutuan (MAIWP), 'Zakat Syarikat yang Bercampur-Campur,' http://www.zakat.com.my/fatwa-zakat, dicapai pada 12 Jun 2016.

Majlis Agama Islam dan Adat Istiadat Melayu Kelantan, 'Zakat Pendapatan,' http://www.e-maik.my/v2/index.php/kalkulator-zakat-pendapatan.html, dicapai pada 14 Julai 2014.

Majlis Fatwa Kebangsaan, 'Pembayaran Zakat oleh Tabung Haji,' http:// www.e-fatwa.gov.my/fatwa-kebangsaan/pembayaran-zakat-olehtabung-haji, dicapai 13 Ogos 2014.

Majlis Fatwa Kebangsaan, 'Pembayaran Zakat oleh Tabung Haji,' http:// www.e-fatwa.gov.my/fatwa-kebangsaan/pembayaran-zakat-olehtabung-haji, dicapai 13 Ogos 2014.

Majlis Fatwa Kebangsaan, 'Zakat Ke atas Syarikat,' http://www.e-fatwa.gov. my/fatwa-kebangsaan/zakat-ke-atas-syarikat, dicapai 13 Ogos 2014.

Majlis Fatwa Kebangsaan, 'Zakat Ke atas Syarikat: Zakat Kumpulan Wang Simpanan Pekerja KWSP,' http://www.e-fatwa.gov.my/fatwakebangsaan/zakat-ke-atas-syarikat, dicapai pada 13 Ogos 2014.

Majma“ Fiqhī al-Islamī al-Dawlī, 'Zakat Saham dalam Syarikat,' http://www. fiqhacademy .org.sa/qrarat/4-3.htm., dicapai 13 Ogos 2014.

Muhammad bin Abi al-Abbas Al-Ramlī, Nihāyah al-Muhtāj ilā Syarh Minhāj; beserta Hāsyiyyah 'Ali bin 'Ali al-Shabralamsī, Hāsyiyah Muhammad bin Ahmad al-Maghzī al-Rāsyid̄̄, vol. 3 (Beirūt: Dār al-Kutub al'Ilmiyyah, cetakan ketiga 2003).

Muhammad bin Abū Bakr al-Rāzī, Mukhtār al-Ṣiḥhah (Lubnan: Maktabah Lubnan, 1986).

Muhammad bin Idrīs al-Shāfi'‘̄, al-Umm, vol. 3, ed. Rifa'āt Fawzī 'Abd alMuțalib (Manșūrah: Dār al-Wafā', 2001).

Muhammad bin Mukram bin Manẓūr, Lisān al- 'Arab, vol. 7 (Beirūt: Dār Șadr, t.t.).

Musțafā Khin, Musțafā Bugho, 'Alī Sharbajī̄, Fiqh al-Manhajī 'alā Madhhab al-Imām al-Shāfi ‘ $i$ (Damsyiq: Dār al-Qalam, cetakan ke 10, 2009).

Sa'id al-Bakrī bin Muhammad Syața al-Dumyațī, Hāsyiyah I'ānah al-Ṭālibīn, vol. 1 (Beirūt: Dār al-Fikr, t.t.). 
Said Bouheraoua, 'Syahsiyyah I'tibariyah- 'Zakah Obligations On Islamic Financial Institutions', ISRA Research Paper, 34 (2012).

Shams al-Dīn Muḥammad bin Aḥmad al-Sharbin̄̄, Mughnī al-Muḥtāj ila Ma 'rifati Ma 'ānì Alfāz al-Minḥāj, vol. 2, ed. Toha 'Abd al-Raūf Sa'd (Qāhirah: Maktabah Tawfiqiyyah, t.t.).

al-Sharbīn̄̄, Muḥammad bin Muḥammad, al-Iqnā' fì Hilli Alfāz Abì Syuja', vol. 1, ed. Muḥammad Mu'awwaḍ, 'Adil Aḥmad 'Abd al-Mawjūd (Beirūt: Dār al-Kutub al-'Ilmiyyah, 2004).

Shihāb al-Dīn Aḥmad bin 'Alī al-'Asqalān̄i, al-Talkhīs al-Khabīr fì Takhrīj Ahāàith al-Rāfi'ì al-Kabìr, ed. Hassan bin 'Abbas (t.tp: Mu'assasah Qurtubah, 1995).

Shihāb al-Dīn Aḥmad bin 'Alī al-'Asqalānī, Fath al-Bārī Syarah Ṣah̄ịh Bukhārī, ed. 'Abd al-Qādir Shaybah al-Hamd (Riyāḍ: Maktabah alMalik Faḥd al-Wațaniyyah, Amir Sulțān 'Abd al-'Azīz, 'Aalī Saud, t.t.).

Shihāb al-Dīn Mahmūd bin Aḥmad al-Zanjānī, Takhrīj al-Furū' 'alā al-Ușūl (Qāhirah: Mu'assasah al-Risālah, t.t.).

Yūsuf al-Qaraḍāwī, Fiqh al-Zakāt, vol. 2 (Qāhirah: Mu'assasah al-Risālah, 2001).

\section{Temu bual}

Mohd Fariz 'Abdul Razak (Pegawai Penyelidik, Lembaga Zakat Selangor (LZS)), dalam temu bual dengan penulis, 20 Jun 2013. 
Jurnal Syariah, Jil. 25, Bil. 2 (2017) 187-216 